\title{
Transition to Democracy in Post-Soviet States: Success or Failure. Case Study Analysis.
}

\author{
Ceyhun Valiyev \\ University of Kassel, Germany
}

\section{Introduction:}

This research project is aimed at analyzing the transition process taking place across the Post-Soviet countries. Especially conducive to fostering of the transition actions in these countries was the collapse of the Soviet Union which paved the way for the potential political, economic, and social changes. However, as a result of deep subject of discussion among transition and democratization theorists, not all, but some of Post-Soviet countries faced successful transitions to democracy. It is still unclear, why most of the ex-Soviet countries have failed to achieve positive changes towards democratization, with only some of them being relatively successful. Certain scholars attempted to generalize the theories developed after the democratization wave covering Latin America and Southern Europe in order to find the answer to this very question. For some others, it was not quite right approach to apply existing developed theories while explaining the transition processes that took place in Latin America and Southern Europe. Thus, new ways have been suggested intending to explain the situation in the Post-Communist and Post-Soviet countries. The question is that there are huge differences within the post-Soviet countries themselves that make them distinctive. This requires additional separate cases to be studied and explored.

The hypotheses developed throughout the project show that not all of the countries which were chosen as case studies don't fit into each of these hypotheses at all. Some of the hypotheses fail to explain the situation in all of these countries. This, however, doesn't mean that these hypotheses are invalid or unreliable. On the contrary, some important finding made as a result of the research was that postSoviet countries all have their own distinctive characteristics rightly explaining the transition processes and correctly addressing the problems existing in each of them. 
What are the main causal factors leading to this outcome? What are the independent variables??? whether transition is successful or unsuccessful depending on the country? Are there certain independent variables that are applicable to some of the Post-Soviet countries but not relevant for addressing the situation in others? Were there any cultural, religious or some other either institutional or structural aspects that have influenced and brought up various outcomes across these countries? Before answering these special questions, it is important to see what other scholars have been saying about the general characteristics of the successful and unsuccessful transitions worldwide, and specifically in Post-Soviet countries. The main underlying topic goal of this paper is to explore why some of these countries are successful but most of them failed to have prosperous transition to democratic ruling system.

The research question that is addressed in this project is a very timely issue and there are plenty of scholarly sources arguing about this topic. In this project, my main aim is not only to readdress this subject again but rather to find out new ideas and variables that could help to explain the reasons for the diversity of the results as an outcome of the transition taking place since early 1990s in some of these countries. In addition to this, it is one of the primary objectives of this paper to settle the dispute or at least make my own contribution to the debate among scholars over whether it is relevant or not to apply the same theoretical framework and evidences from other parts of the world (especially in Latin America and South Europe) in order to explain the transition processes going on in Post-Soviet countries. For instance, Karl argues that although these are different cases we can still make some generalizations about such regions as Latin American and PostSoviet region countries (Karl, 2002). On the other hand, Bunce claims that the differences outweigh the similarities among these regions which in its turn is very unhelpful for making generalizations (Bunce, 2002). In overall, it is one of my unchanging positions throughout this paper that Post-Soviet countries are not only different in comparison with the regions mentioned above, but rather there are even huge varieties among Post-Soviet countries that need to be explained, as this has led to different paths during the transition period. Since it is not the main aim of this research and also, we have time and space restrictions, I will not concentrate on comparisons between regional similarities and differences. However, in the last part of this work, I will give my stated position as to whether we can compare these regions at all.

Another theoretical importance of this research paper is reflected in the fact that since it is a case study analysis, it will give me an extraordinary opportunity to explore each case in depth and to analyze the basic hindrances or preconditions of democratization. In other words, concentrating on some of the Post-Soviet 
countries, I will examine the variables explaining the conditions across these countries which show the reasons for success or failure within the democratization process. Also, I would like to note that my cases are Lithuania, Georgia, Azerbaijan, Belarus and Uzbekistan. However, I will give my own logical reasoning for selecting these cases for my research project in the Data and Methods section.

We know that the U.S., EU and some other regional organizations are concerned about the spread of democracy within the post-communist Eastern Europe and Post-Soviet countries, in Caucasus and Central Asia. By objective explanation and analysis of the preconditions for successful transitions, we can practically suggest a new set of ideas which can be applied in new projects by statesmen and policymakers. Moreover, the threat coming from failed states can be another reason that increases the importance of this project to be taken into consideration by policy makers. In this respect, certain essential actions could be taken in order to assist the democratization of these countries rather than letting them flow towards authoritarianism. Another difficulty is that the activists within these countries can also see what the problems are and what prevents the democratization process from going smoothly, thus helping them to be better organized and taking some more concrete steps.

Though there will be a lot of common grounds among the cases that are the subject of study, there will also be some specific variables that are only characteristic of a case or two. It means that the politicians, organizations and other social activists who are interested in helping the democratization process in these countries can have clear set of ideas about each country, so the trap of overgeneralization can be avoided eventually.

\section{Literature Review and Stated Hypotheses}

In this following and main part of the paper, the objective is to explore the literature in terms of what kinds of scholarly sources are found in the field of democratization, transition studies and what have been told by salient figures in this field of Political Science. The In-depth exploration of the literature will light our way on accomplishing this project and facilitating it with an intention to initially see what the factors leading to successful democratization or vice versa are, and what the causes of failure of the transition to democracy are. As a logical result, some hypotheses will be developed due to the found literature from democratization and transition studies. It is worth noting that we will try to analyze 
the sources not only specifically related to Post-Soviet studies, but will also include the sources that generally talk about the democratization theories in particular.

\section{Definitions}

Since there is an ongoing dispute among scholars about the definite notion of democracy, it is better to initially explain what ideas have been developed by scholars about the definition of democracy. It is to be emphasized that everyone has his/her objective view of democracy and scholars have come to different conclusions regarding this concept. Some people see democracy or democratization (both are mainly the same supplementary concepts) only as free and fair elections and adding some basic norms that make elections possible, yet some others prefer to have liberal individual rights to be respected and recognized in any democratic country. Schumpeter, who is very famous for his minimalist approach towards democracy, states that it is an institutional arrangement to reach political decisions in which individuals acquire power to decide by means of a competitive struggle for the people's vote (Schumpeter, 1976). In my opinion, we can't necessarily argue that if there are free and fair elections it is a democratic regime. We should be considerate of not only elections but also of human rights and civil liberties that comprise the base for democracy in a real sense. In his salient work called "The Rise of Illiberal Democracy", Zakaria calls these kinds of regime "electoral" democracies which have elections (supposed to be free and fair), with basic human rights and liberties not protected or provided by the state (Zakaria, 1997). Furthermore, Fish argues that democracy is more than a right to vote such as a right to communicate and associate (Fish, 2001). Moreover, Roeder defines democracy as the ability of half of the people to remove the incumbent officials (Roeder, 2001). Yet, Beetham, in his turn, says that "democracy is a mode of decision-making about collectively binding rules and policies over which the people exercise control" (Beetham 1992: 40). Simply put, democracy is the rule by the people (Grugel, 2002). "Modern political democracy is a system of governance in which rulers are held accountable for their actions in the public realm by citizens, acting indirectly through the competition and cooperation of their elected representatives" (Schmitter and Karl, 1991, p-76). Before starting to lay down and explain my own hypotheses, it is very important to mention that while claiming these hypotheses, I did not use the cases as an evidence in order to avoid the tautology trap, unless I was trying to explain some complicated and controversial situations regarding each of the hypotheses. 


\section{H1. Economic development is one of the major factors leading to democratization in transition countries}

In fact, it is one of the most significant but at the same time disputable hypotheses for which some scholars give credit but some others underestimate its role defining it as that of the one not belonging to the significant pre-requisites for democratization. Thus, it is vital to first analyze and clarify the arguments of both sides with further statement of my own position and explaining my reasoning for that. Mostly known as modernization theorists, some scholars argue that it is capitalism and economic development that lead to democracy. A well-known proponent of this school is Lipset who states that there is a positive correlation between economic development and democracy. According to the data represented in his research, Lipset (1959) states that "the average wealth, degree of industrialization and urbanization, and level of education are much higher for the more democratic countries" (p-6). Thus, Lipset perceives industrialization, wealth, income, educational level as either intervening variables or preconditions for democratization, though some of these will be used as independent variables in the following parts. Grugel also states that, for Lipset, capitalism is at the heart of democracy, and education also has a positive effect on democratization, which helps to increase the middle class (Grugel, 2002). Moreover, Kugler and Feng view economic development as a macro level factor that affects democratization (Kugler/Feng, 1999). Additionally, Muller (1995) claims that economic development and democratization have strong positive relationship so that democratization is likely to occur in countries that have intermediate economic development. Furthermore, Feng and Zak (1999) argue that with sufficient economic growth non-democratic countries almost become democratic ones.

However, there are plenty of authors showing their obvious disagreement with the above mentioned statement, and providing some counter arguments. For instance, O'Donell's (1973) theory of bureaucratic authoritarianism shows that the deepening of capitalism in developing countries results in the emergence of dictatorships. Huntington and Nelson show that economic growth can occur but it cannot be equally distributed, which can lead to a conflict and nondemocratic consolidation (Huntington and Nelson, 1976). Larry Diamond also backs up an interesting idea by stating that economic development will lead to democratization only if it positively affects civil society, creates state-society relationship, culture and class structure (Diamond, 1992) So, the major argument which is claimed by oppositionists is that economic development does not necessarily lead to democracy, though it can be a factor for consolidation. 
For me, economic development has a vital role within the democratization process but if we take into consideration the cases studied in this research, it seems that not in all of them it is applicable. If we look closer at the statistics showing economic development we will see controversies occurring in my case studies. We will come back to this point in the results and conclusion section.

\section{H2. GDP per capita is also a facilitating cause of democratization}

This is an idea that should have an obvious positive effect on the democratization process. It is logical to argue that there is a positive relationship between GDP per capita and democratic development. But we should not confuse GDP per capita with GDP annual growth rate, while the latter can't be a necessary factor helping democratization, since it might be distributed rather unfairly. According to findings of Feng and Zak, GDP per capita is one of the significant factors playing an important role in the overall democratization process.

\section{H3. High education and literacy rate is one of the factors accelerating the transition to democracy}

This is an argument made by several scholars (Lipset, 1959, Feng and Zak, 1999), according to which a high rate of education is one of the causes conditioning democratic environment. In normal conditions, it is supposed to be a really crucial condition because uneducated people will not be that interested in having more rights and demands. However, our case studies reflect some controversy and show that it is not always true. For instance, according to UN Data (2005) on education and literacy in different countries, Belarus and Lithuania which are not free as well as countries in Freedom House Report (2007) respectively, have the highest level of literacy rate $(100 \%)$.

This is a very confusing situation which shows that we don't have to really fixed hypotheses applying to all of these cases at once, except some of them that we will discuss further. As it has been stated at the beginning, it is a major finding of this research that each country has its specific reasons for being democratic or nondemocratic which makes these post-Soviet countries exceptional in some sense.

\section{H4. Equal distribution of income (wealth) is the other precursor for democratization.}

We know that every country can be wealthy but not democratic because of the unequal or unfair distribution of wealth among people. As a result of unfair distribution, only a small group of people benefit from revenues and the majority lives poorly. Actually, if we refer back to the idea of Lipset (1959), it becomes 
obvious that the middle class is another factor which facilitates democratization. This is, however, a dependent variable of equal distribution of wealth or income because there will not be any potential for most of the people to become a middle class as a result of unequal distribution. It would be better to add another intervening variable which is high level of income. Again, in my opinion, there can exist high level of income but this income may not be proportionally equal among all social groups excluding most of the people. Burkhart (1997) argues that not only the lower level of democracy creates inequality within income distribution but also that unfair income distribution either decreases the level of democracy or impedes the democratization as well. Feng and Zak also define the role of fair distribution of wealth as being one of the primary factors for democratization (1999). I did not separate the notions such as wealth, income and equal distribution of it because it is proved hypothesis that without equal distribution of income there can't be a precondition for democracy. So, logically, these intervening variables such as wealth and income require "if" in order to serve as a condition for the democratization process, and this "if" precedes the notion of "equal distribution of wealth or income". Referring to Azerbaijan, one of case studies, has huge oil income and high GDP annual growth rate $(25 \%$ in 2005$)$ which means this country is supposed to be democratic if we apply the income effect theory to democratization. But in Freedom House Data (2007) it is indicated as one of the non-free states. This is the reason that, in my opinion, McFaul calls the transition in these countries as the "forth wave" (2002).

\section{H5. Accountable state is a necessary aspect of success in the democratization process}

The accountable state theory, being one of the major preconditions for democratization, is strongly argued by most scholars of the democratization studies who are concentrated on structural factors. Grugel claims that democratization means having a democratic state and it requires both, representative and institutional changes along with functional transformation. He further says that states can be impediment against democratization but it is the state that promises for the welfare of its people. Actually, he is not the only one supporting this standpoint, since Bunce also suggests that a strong state is the guarantor of democracy as much as it is of capitalism (Bunce, 2000). According to Schmitter and Karl (1991), accountability of rulers is one of the signs of democratic environment in any country. The rulers are held accountable for their obligations without being allowed to abuse their privileged positions, otherwise they are overthrown during the following elections or as a result of popular impeachment. Thus, in case of bad performance, people can overthrow the rulers who, in their opinion, are not considered to be relevant. However, for this purpose we need 
strong, active and mobile civil society which we will touch upon later (Grugel, 2002). Thus, it seems that the existence of accountable government is one of the conditions required to lead the overall democratization process. Actually, this concept does not cause intense debate among scholars, since most of them recognize the role of accountable state.

\section{H6. Civil society is another factor assisting to be successful in transition process}

Actually, civil society notion is one of the signs of democracy and it is also perceived as the crucial source for democratization in transition countries. If we again refer to Schmitter and Karl, whose work is mainly concentrated on the characteristics of democracy, it becomes obvious that they value the role of civil society as one of the circumstances for democracy or democratization (1991). Furthermore, Dryzek also accepts the important role of civil society and the passively exclusive state (which paves the way for civil society to function) as crucial for further democratization of a country. However, for Dryzek, the push for democratization comes from civil society rather than the state itself, yet he does not ignore the state that values the existence of civil society (Dryzek, 1996). In addition, Petova also states that civil society is the condition not only for democracy but also for development (2007).

\section{H7. The existence of informal institutions is also the cause of failure in the democratization process}

Another impediment standing on the way to democratization is the role of the informal institutions. For Smolar, there is no strong civil society in the Post-Soviet countries and their role was especially decreased because of the unwillingness of the elite to compromise and adopt reforms towards democratization (Smolar, 2002). Higley and others argue that although the Soviet Union collapsed, the old elite still holds power, especially in the administrative and economic branches (Higley/Kullberg/Pakulski, 2002).

Thus, we see from the analysis of the hypotheses that some of them are totally valid and some are true in only one case or two. In my opinion, it doesn't decrease the importance of the conducted research, on the contrary, it is a cautious signal for scholars, (who make attempts in generalizing some concepts that have been developed as a result of democratization in Latin America and Southern Europe), that the post-Soviet countries are different cases and they have to be analyzed from various and special aspects rather than by applying all the theories to each of them. This is the problem that creates the so-called "application fallacy" which means that there are misleading applications of theories to the post-Soviet countries that 
have been developed in order to analyze the conditions in some different cases. This is a dangerous situation and a challenge not only to Political Science but also, to practical life, since statesmen and activists can come to wrong conclusions as a result of incorrect generalizations and, thus will not be completely effective in their attempts to democratize the post-Soviet countries.

I argue that in future, we might have the new "fifth wave" of democratization among these post-Soviet countries which would bring up new ideas and conditions for us to develop new theories about the democratization processes in the postSoviet countries that will totally ignore the role of current hypotheses. We should not forget that in social sciences truth is tentative.

Before going to the Data and Methods section of the research project, it would be useful to analyze some other hypotheses that were not added to the above mentioned list due to specific reasons regarding each of them. For instance, some argue that the regional proximity to Europe is one of the reasons that caused successful transition in some of the post-communist countries (Lankina and Getachew, 2006). But it is not applicable to explaining the situation in Belarus and Georgia from the point of view that the former is closer to Europe but is characterized as non-free (Freedom House Report, 2007), whereas the latter is on the right path towards democratization, though being far from Europe compared to Belarus.

Since the times of Weber, there is strong support for the argument that democracy is a compatible option among Protestant Christian countries. However, as Huntington (1991) says, as shows a result of the "third wave" of democratization, it is not a dream among Catholic states of Southern Europe. Our case study, Lithuania is also dominantly Catholic state which is a democratic country. It is beyond our topic, nevertheless worth saying that East Asian countries unlike any of the Christian countries, have Confucian affiliation but this did not impede them to follow the path of democracy during the "third wave" of democratization. As Huntington states, culture and religion are subjects to changes and in regard to the conditions we can witness democratization of two Muslim countries which are our case studies,e Azerbaijan and Uzbekistan (Huntington, 1991).

\section{Data and Methods Section}

In this part, the data and methods which are used to measure the variables, their validity and reliability, will be analyzed. If we refer to the literature review part of the paper, it becomes clear that there are seven major independent variables which 
are keys to explaining our dependent variable (What are the factors causing successful or unsuccessful transitions in some Post-Soviet countries). The variables are as follows: economic development, GDP per capita, unequal or equal distribution of wealth, education and literacy rate, accountable or responsible state, civil society and last but not least, informal institutions. It is vital to emphasize that the problems related to the measurement of these variables will be notified as soon as the measurement techniques are discussed.

However, before going on to exploring the variables and the measurement tools for each of them, it would be useful to rather see in details as to why I chose these countries as my case studies. My case studies are Lithuania, Georgia, Azerbaijan, Belarus and Uzbekistan. First of all, I tried to choose cases that are in different phases of their development. For instance, Lithuania which is a free state according to the Freedom House Report (2007), and Belarus or Uzbekistan that are not free at all due to the same source. Georgia, which is in the middle of its way, has had substantial democratic trends over the last couple of years. Azerbaijan is also noted as a non-free state in the freedom House Reports, but it is characterized by slightly more democracy than Uzbekistan or Belarus. The second reason why I have countries which vary according to their level of democratic development is to check validity of my arguments laid throughout the paper in a more reliable way, since we have three types of rules in these countries - democratic, moderate and non-democratic or in other words, free, partly free and non free. My preference of these case studies is also based on picking up from different post-Soviet regions that they are located in, such as Baltic region, Eastern Europe, Caucasia and Central Asia. In my opinion, by doing this, we could find much more differences rather than similarities among these cases in their transition experience.

So, to measure the first variable which is economic development, several factors were explored such as Gini and Human Development Indexes (HDI) and GDP per capita, poverty index and unemployment rate. The first four measures are derived from the Human development Index (HDI, 2007/08), whereas the last two are from Data found in World Bank Data Set (2004). Gini Index is a measure of income inequality which describes deviation of income or consumption distribution from perfect equality. A score of zero implies perfect equality while a score of 100 implies perfect inequality. HDI is generally used to measure the quality of life by combining health, lifespan, education and the standard of living. "Gross Domestic Product (GDP) per capita is the total annual output of a country's economy per person". The Human Poverty Index is a composite indicator that shows a population's deprivation from the point of view of three development goals: health, literacy, and the sufficient standard of living. The index is scaled from 0 to 100 , with 100 representing the highest possible level of poverty. Total Unemployment is 
defined as the percentage of the total labor force which is simultaneous with an indication of those without work, available to work, and actively seeking work. (World Bank, 2004). Thus, these are the measures that will help us to see the validity and reliability of our arguments.

The second variable is GDP per capita which we have already noted while showing the measurement tool for the economic development variable, since GDP is the major part of economic development. Here, we also use Data from HDI (2008) and World Bank Data Set (2004) in order to check the validity of our variables. As it was mentioned above, GDP per capita is the total annual output of a country's economy divided by the population of the country for that year (World, Bank, 2004).

The next variable is the equal distribution of income among people. There is also a specific measurement way in World Bank Data Set that helps us very much. It is called income inequality which measures expenditures in different countries, including the case studies of this research project.

Another variable that will be measured is the literacy and education rate. We, again, refer to the World Bank Data Set and HDI in order to measure this variable too. According to the World Bank (2004), Literacy Rate measures the proportion of the population in a specific age group who can both, read and write with understanding a short, simple statement in their everyday life. In addition, it can be adult of youth literacy rate, depending on the objective of the study such as if we are measuring the education and literacy rate among youth or the overall population who are above the age of fifteen. In the HDI Report, it is indicated that the literacy rate doesn't only include the adult literacy rate but also, the primary, secondary and tertiary school enrollment of students. The World Bank (2004) made an important note claiming that if the literacy rate is not available from the country of study, the generalization is made according to data gained from the neighbors of this country. In my opinion, this creates a problem that overgeneralization can occur and we can have false measurements as a result. The reliability and at the same time validity of the measurement of the variable potentially decreases in this case. The other difficulty is that HDI only measures the enrollment of students to different levels of schools but it doesn't consider the potential non-attendance of students to classes despite them being enrolled and their names being stated on the sheet.

Another question related to the measurement of GDP especially in developing countries is related to the existence of the informal economic activities that inhibit from getting accurate data about each country. Generally, most of data about 
developing countries (where four of my cases are included, except Lithuania) are collected from the Household surveys which are not reliable at all, since biases can occur while answering the surveys. In case of the income inequality measure, as World Bank Data Set (2004) shows, there can be clear inter-coder reliability problems related to the measurement of this variable, since each survey can use different indices such as consumption or income in order to measure inequality. It was also mentioned that households can have different size of incomes and expenditures which also creates uncertainty about the measurement.

Furthermore, the HDI Report also warns us that this index is not a comprehensive measure, since it doesn't include income inequality and other more difficult variables to measure, for instance, human rights and freedom. As it is noted above, due to World Bank Data Set, we have already indicated the income inequality measurement, though the measurement problems were recognized.

If we look at the above reasons, we see that they are basically the measurable variables, since they are mainly economic variables, and we have some specific ways to measure them despite certain still existing problems which were noted above as clear as possible.

Our next variable which is an accountable or responsible state is very difficult one to measure and explore in depth. I will try to put some different measures on my own, since I have not come across any Data measuring the accountable state variable. In my opinion, the existence of check and balances, as well as distribution of power between the executive branch and legislature is one way of measuring an accountable state, since legislature imposes some restrictions which prevent the executive branch from acting irresponsibly. The inefficient judiciary, which is related to the first way of measurement, can also be used as a factor to measure the level of accountability, since ineffective judiciary is less is less conducive to the irresponsible actions of the government.

The other way to measure this variable is to look at the level of corruption that exists in the country, since non-accountable states are characterized by high level of corruption and bribery. It is to be noted that these are the characteristics stated in the Freedom House Report in relation to countries while describing the conditions existing there, even though they are not clearly mentioned as the measurements for an accountable state.

Freedom House uses surveys in order to collect information from every single country in order to assess the level of political and civil liberties, and they have special representatives visiting each of these countries or they have their permanent regional or country offices. 
The other variable that was indicated is the existence of civil society which is hard one to measure too. Some scholars, such as Petrova (2007), also recognize the difficulty of measuring this concept. In this part, I will apply the Freedom House report in order to measure the level of civil society. In my opinion, the civil and political liberties are the main pre-conditions for the existence of civil society in any country. If there is no pressure and repression of civil organizations, NGOs and media, if the civil society groups can actively intervene in daily life and have immeasurable affect on domestic and external politics of the government, then we can say that there is a strong civil society in this or that country. Or, the situation can cycle otherwise.

Since countries are called free, partly free and not-free due to political and civil liberties in the Freedom House Report, we can conclude that strong, weak and almost non-effective civil societies exist in free, partly-free and non-free countries which are labeled by the Freedom House Report. It is a logical sum up since there is a high correlation between civil and political liberties, civil society and the status of the country in the Freedom House Report. As we basically refer to the Freedom House Report in its characterization of countries, it would be better to recognize some possible problems beforehand.

In the last report of Freedom House, two questions regarding how to measure civil and political liberties have been added, which means that there are some differences in measurement of the results obtained in the last Report (2007) compared to previous Reports.

This is the actual problem of the reliability over time that can occur in the measurement of variables throughout these countries if we compare them across years. Also, since each country is surveyed by different persons they can have their own preferences in the course of asking questions which can also give different results. It can be a problem which is sometimes referred to as inter-coder reliability.

My last variable that is to be measured is the informal institutions which is the most difficult to measure in practice because they rarely exist in reality, for example in patron-client relationship???. However, we still have some ways to measure this variable too. The informal set of relationship grows when there is lack of societal organization and as a result, the personal, traditional or ethnic affiliations within the ruling group strengthen (Grzymala-Busse and Luong, 2002). Finally, as Kuzio (2000) argues, when there are no strong national identity and effective state institutions, the informal rule prevails. The existence of informal ties 
and patron-client relationship detaches the elite from people and as a result, it becomes non-responsive to the needs of people.

The non-existence of the rule of law which is derived from the weak state structure also creates opportunity for the development of the informal institutions (Gel'man, 2003). So, these are also the four measures, namely the lack of societal organization, national identity building, no rule of law and in-effective state institutions.

Concerning the internal and external validity of my variables, it would be worth saying that not all of my hypotheses are valid and applicable to all of the case studies. It doesn't mean that these hypotheses are invalid at all or they can't even have external validity as well. I would rather say that it is one of the interesting parts of this research project which creates complications and makes author think about, analyze and come to his own conclusion about the hypotheses and case studies. In the literature review part, in order to avoid the tautology, as it was noted above, we did not try to use the case studies in order to prove the correctness of the hypotheses. Rather, it was more useful to leave the discussion about the applicability of some hypotheses to some specific cases and the others till the very last part of the paper. Speaking about the external validity, one can say that, although these cases are very distinctive and have certain characters that are not peculiar to other post-Soviet countries, we can still find lots of variables that explain the situation in Armenia and Kazakhstan which were helpful while elaborating the process in Azerbaijan and Uzbekistan respectively. At international level, we can't say promising words, since the Post-Soviet countries have very specific features, with each of them having distinct roots in their transition periods. But we never know, because the collapse of communism in any current communist state such as Cuba or North Korea, for instance, might be object of study these variables' validity. The same relates to some African countries too.

So, generally, these were the variables that I tried to show in connection with the measurement ways that are useful in order to define their reliability and validity. As we saw, there are several problems related to the measurement capacity of Data Set and the Freedom House Report that we use. It is certainly obvious that there might be other sources which could be more effective and valid to measure our variables but we should consider the time constraints (also our lack of capacity and experience) that prevent us from having in-depth research and more objective and trustful analysis of the research question. If we make a long term research and an in-depth analysis of the variables and the cases, we can find different results. It is possible, since every new deeper research has its own new implications for social sciences. The practical side of the issue is that currently, there are ongoing 
transitions in the region countries, as to which any changes occurring there would be enough to modify the relationship among some of the independent and dependent variables or even ignore some of them at all.

\section{Results and Discussion}

In this part of the paper, the major findings will be analyzed in combination with referring back to the literature discussed in the review part of the paper. Each hypothesis and its validity will be tested throughout our case studies.

Our first hypothesis was the economic development theory and its role in the democratization process during the transition period. As it was shown above, there were several measurements for this variable such as GDP per capita, Gini and HDI Indexes, poverty index, unemployment rate and others. The main point is that when we look at Data Sets found in HDI and the World Bank, we see some controversy which ignores the relevance of this hypothesis to all cases that we have. It is worth noting that Belarus, according to the World Bank (2004), has higher Human Development Index (Belarus, 0. 79) than Azerbaijan (0.75) and Georgia (0.74) but it is obviously less democratic not only compared to Georgia but even relatively less democratic than Azerbaijan. Gel'man also claims this idea concerning Belorus having high Human Development Index but low democratic indications creates controversy (2003). However, it is not an issue in case of Lithuania who has the highest HDI Index and also has the "free" status in the Freedom House Report (2007). So, depending on cases that we study, the range of influence of economic development on democratization varies.

It is also a problematic issue when we look at the unemployment rate which is another measurement of economic development, as it does not show the reality existing in these countries such as Lithuania, being the most unemployed country among our cases but having democratic regime. It is very important to note that, may be, I could not find the right direction of the causation due to not enough research on this specific issue. However, it is still a valid argument (economic development) to claim, since it is a factor in some of the cases analyzed.

GDP per capita which is also another variable, at the same time being measure of the economic development, is also a highlighting factor for the democratization of a country. Lithuania, shown as a free nation in the Freedom House's Report about Nations (2007), has the highest GDP per capita (\$15.000) among our cases in HDI for 2005, whereas Uzbekistan has the lowest GDP (\$2000). The variable that GDP per capita has positive relationship with democratization is true in this sense, 
however, when we see that Georgia's GDP (\$ 3.365) is lower than that of Belarus (\$ 7.918), we change our position that it is not applicable in all our cases. So, this hypothesis is basically true in our cases but as it was mentioned above, it is one of the main conditionalities in the post-Soviet countries with each having distinctive features characterizing them has either successful transition to democracy or failure.

The income equality is another factor that facilitates the democratization process. However, here again, we face controversy in case of these full complex Post-Soviet states. Uzbekistan (26\%, with 0 being perfect equality) has the least income inequality compared to other countries but it is labeled as a non-free country in the Freedom House List (2007). Moreover, inequality of income distribution is almost in the same percentage between Belarus and Lithuania, $30 \%$ and $31 \%$ respectively. However, the Freedom House Report shows totally contradictory results, according to which the latter is free and the former is not a free country.

Literacy and education rate is another hypothesis argued that was aimed at being as another factor assisting in the democratization. Yet, we face some puzzling situation here too. For instance, Lithuania and Belarus have again almost the same literacy rate which is around 100 percent, with Uzbekistan having 99 percent. But we know that neither Uzbekistan nor Belarus is democratic and they are not even on the free list of Freedom House (2007). It is also a non-applicable hypothesis to most of our cases, except Lithuania.

The following hypothesis is about the role of an accountable state in the democratization process. In the Data and Methods section, we found out three basic measurements for this variable, those are the lack of check and balances between legislative and executive bodies, ineffective judiciary system and also vast amount of corruption. Actually, if we look through each of these countries we can see that except for Lithuania, and in some issues Georgia, these are the factors that prevail in political life of Uzbekistan, Azerbaijan and Belarus. As a logical outcome, these countries are labeled as non-free in the Freedom House Reports. The unfortunate situation is that the ongoing transition of these countries from slight democracy to non-democratic system goes on. If we compare these countries across the years, one can see that none of these countries has taken a step forward. It is only Georgia that has democratic trends.

I want to note one important thought that when we make comparison between Lithuania and the other four countries, our hypotheses will not, of course, work at all. That is why, it is better to take into consideration the international measurements for economic development, income equality, GDP per capita, high 
educational rate and etc. If economic development is not a reason for the democratization in these countries, it means, under-development is the cause of the nondemocratic situation within them.

Our next hypothesis is the civil society and its role in the democratization process. As it was indicated above, there is a highly positive relationship between existing political-civil rights and activeness of the civil society. This is proven in the Report of the Freedom House too (2007). So, if we see that Lithuania is called a free state, we can definitely argue that there is a strong civil society in this country, however it is totally vice-versa in Belarus and Uzbekistan cases, whereas the countries are not free and there are almost no civil society groups or activists. Azerbaijan is also labeled as non-free, however the thing is that there is a slightly active civil society in this country but it is weaker in its turn, compared to Georgia, which is partly free according to the Freedom House Report (2007).

Finally, the informal institutions and their impeding character in front of the democratization process is the last hypothesis argued in this research project in the literature review part. We also used some measurements in the Data and Methods Section such as lack of societal organization, weak state structure, lack of rule of law and national identity crisis. Here, we refer to the sources such as Kuzio (2000) who argues that the existence of the informal institutions in Belarus and Central Asia is due to weak societal institutions, or simply non-existence of civil society and national identity among people. Collins also argues that there is lack of national identity and the formal state structure is not effective which creates a haven for the development of the informal institutions (2002). Furthermore, Guliyev (2005) states that in Azerbaijan, the weak formal state structure, ineffective rule of law creates opportunities for the informal set of relations. Lithuania does not have problems such as the informal institutions, ineffective rule of law, corruption, weak civil society and others which would impede the democratization there.

Thus, we saw income inequality represents by itself one of the hypotheses stated in the beginning which is an exception, since it is not relevant at all to any case study in this research project. However, one should note that because of the constraints and limited research on the topic we might mistakenly express some of the hypotheses that are not correct in reality. In the last part of the paper, I will give my basic findings and conclude the project by making some predictions. 


\section{Conclusions, Future Research and Forecasts}

As a result of this research project, some conclusions were made about the postSoviet countries which were the case studies. The first and most important finding is that each of these countries has certain characteristics which explain why these countries succeeded or failed in becoming democratized after almost two decades of independence.

Practically, our economic hypotheses were ignored in most of the cases, however, if we, again, consider them at international level, we would see that they don't have real economic development, GDP per capita income and income equality. So, indirectly, these are also the factors that prevent democratization. This doesn't let us argue that economic factors did not play such a great role in the democratization process in these countries, except for Lithuania. They did play a great role but they are still not factors in these countries, that is the point. So, our findings show that economic underdevelopment, high income equality, low GDP per capita income are, in other words, impediments to democratization of these countries from the economic point of view.

Political and institutional problems such as weak civil society, irresponsive government, informal institutions are also factors that showed up.

Shortly, post-Soviet countries have problems with the variables that exist within them, thus impeding the overall democratization process. These are informal institutions, lack of rule of law, ineffective state and others. Along with that, there are some other economic factors that are typical of these countries such as high human index, low poverty, high GDP per capita income, low unemployment rate and so on. So, these are not the factors that impede democratization there, moreover, these are the factors that these countries need to absorb. Thus, the first four variables necessarily need to exist in the post-Soviet countries, whereas the last 3 variables are to be avoided.

In conclusion, we can easily predict that Lithuania will successfully step forward to develop itself in political and economic terms. But we can't say the same about Georgia which is strongly influenced by outside factors such Russia. However, successful steps towards democratization in Georgia can serve as a motivating factor among the peoples of its neighbors such as Azerbaijan and Armenia, and popular upheavals can be increased in these countries too. Belarus can be influenced by the process going on in neighbor Ukraine. It seems that currently, the governments in these non-democratic countries are not willing to easily give up their position and compromise with the people. Informal institutions, patron-client relationship, personal rule of the individuals are dominant in these countries. 
However, the activities started at grassroots level among people would gradually get power and become a vital factor in politics.

\section{References and Notes:}

Books:

Beetham. D, 1992, "Liberal Democracy and the Limits of Democratization", Political Studies, Vol 40

Higley. J, Kullberg, J./ Pakuliski, J. 2002, ed by Larry Diamond and Marc F. Plattner, Democracy after Communism, The John Hopkins University Press

Fish. M. S, 2001, "The Dynamics of Democratic Erosion", The Post-Communism and Theory of Democracy, Princeton University Press

Huntington, S. P. /Nelson, J. M. 1976, "No Easy Choice: Political participation in developing countries", Harvard University Press

O'Donnell. G, 1973, Modernization and Bureaucratic Authoritarianism: Studies in South American Politics, University of California Press

Roeder. P. G, 2001, The Rejection of Authoritarianism”, the Post-Communism and The ory of Democracy, Princeton University Press

Schumpeter. J, 1976, “Capitalism, Socialism and Democracy”, London: George Allen/Unwin

Smolar, A. 2002, "Civil Society after Communism", ed by Larry Diamond and Marc F. Plattner, Democracy after Communism, The John Hopkins University Press

Articles:

Bunce, V. 2000, "Comparative Democratization. Big and Bounded Generalizations", Comparative Political Studies, Vol 33, pp-703-734

Bunce. V, 2002, "Comparing East and South", ed by Larry Diamond and Marc F. Plattner, Democracy After Communism, The John Hopkins University Press

Diamond, L. 1992, "Economic Development and Democracy Reconsidered", The American Behavioral, Vol 35

Diamond, L. 2002, “Assessing Global Democratization a Decade after the Communist Collapse", Address to the Workshop on Democratization. New Europe College and Romanian Academic Society, Bucharest

Dryzek, J. S. 1996, "Political inclusion and the dynamics of democratization", American Political Science Review

Grugel, J. 2002, "Democratization. A critical Introduction", PALGRAVE

Huntington, S. P. 1991, “ Democracy's Third Wave”, Journal of Democracy Vol.2. No.2

Karl. T. L. 2002, "Concepts, Assumptions and Hypotheses about Democratization: Reflections on stretching from south to east", Center for Democracy

Kugler. J, Feng. Y, 1999, “Explaining and Modeling. Democratic Transitions”, Jorunal of Conflict Resolution, Vol 43, pp-139-146

Lipset. S. M, 1959, Some Social Requisites of Democracy: Economic Development and Political Legitimacy The American Political Science Review, Vol. 53, No. 1. pp. 69105

Lankina, T. V./ Getachew, L. 2006, “A Geographical Incremental; Theory of Democratization Territory, Aid, and Democracy in Post-communist Regions", World Politics

Zakaria, F. 1997, The Rise of Illiberal Democracy, Foreign Affairs 
Schmitter, C.P / Lynn. K, 1991, What Democracy is and is not, Journal of Democracy

Muller, Edward N; Bollen, Kenneth A; Jackman, Robert W, 1995, Economic determinants of democracy

American Sociological Review

Burkhart. R., 1997, Comparative Democracy and Income Distribution: Shape and direction of the causal arrow, The Journal of Politics

Feng. Y/ Zak. P. 1999, The Determinants of Democratic Transitions, Journal of Conflict Resolutions

McFaul. M. 2002, “The Forth Wave of Democracy and Dictatorship", World Politics

Petrova. V. P 2007, Civil Society in Post-Communist Eastern Europe and Eurasia: A CrossNational Analysis of Micro- and Macro-Factors, World Development

Collins. K. 2002. Clans, Pacts and Politics in Central Asia, Journal of Democracy 13.3

Colomer. M. J. 1995. Strategies and Outcomes in Eastern Europe. Journal of Democracy 6.2 74-85

Fukuyama. F. 1995. The Primacy of Culture, Journal of Democracy 6.1 7-14

Eke. M.S. and Kuzio. T, 2000, Sultanism in Eastern Europe: The Socio-Political Roots of Authoritarian Populism in Belarus Europe-Asia Studies, Vol. 52, No. 3. pp. 523-547

Levitsky. S. and Helmke. G. 2004, Informal Institutions and Comparative Politics: A Research Agenda, Perspectives on Politics, Vol. 2, No. 4. pp. 725-740

Freedom House Report 2007

http://www.freedomhouse.org/template.cfm?page $=21 \&$ year $=2007$

Guliyev. F. 2005. Post-Soviet Azerbaijan: Transition to Sultanistic Semiauthoritarianism?

An Attempt at Conceptualization, Demokratizatsiya

Human Development Index 2008, HDI

http://hdr.undp.org/xmlsearch/reportSearch?y $=2006 \& \mathrm{c}=\mathrm{n}$

$\% 3 \mathrm{ABelarus} \& \mathrm{t}=$ incomes and economic growth

$\% 3$ AEconomic + Growth $\bar{k} \mathrm{k}=$ \&orderby=year

http://web.worldbank.org/WBSITE/EXTERNAL/DATASTATISTICS/0, contentMDK:203 98986 menuPK:64133163 pagePK:64133150 piPK:64133175 theSitePK:239419,0 $\underline{0 . h t m l}$ 


\section{Summary \\ Transition to Democracy in Post-Soviet States: Success or Failure. Case Study Analysis.}

\section{Ceyhun Valiyev}

\section{University of Kassel, Germany}

The democratization of Post-Soviet states in past two decades is the subject of this academic study. The main question of this research is that why most of the PostSoviet states haven't gone through successful transition to democracy. Five countries; Azerbaijan, Belorussia, Georgia, Lithuania and Uzbekistan are the cases of this study to analyze and evaluate as empirical part of this work. I haven't chosen the countries that have standard and equal level of success or failure. For instance, Lithuania is among those countries that have gone through quite successful process of democratization, whereas others have similar or different problems hindering the full-fledged democratization across the Post-Soviet area. In some other cases, such as in Georgia the transition has not been fully successful but some measures of democracy are considered to be existent in state institutions and society. Several hypotheses have been developed throughout this study all arguing the preconditions that lead to democratization, then these hypotheses are checked if they are applicable in the cases used in this study. The conclusion is that not all these hypotheses are correct in every single case and each case study has its own characteristic causes that lead to failure or success in transition to democracy.

Key Words: democratization, Post-Soviet states, transition, failure of democracy 